\title{
CAST OF MAIN CHARACTERS
}

\section{Family}

Sara Maria Erffens

Hendrick Mommers

Cunegonde (Cunigunda) Sister of Hendrick

Mommers

Mathias Erffens

Johannes Wilhelmus Bosten (Father Bosten)

Frans Hendrick Bosten

Quirinus Finck
Wife of Hendrick Mommers

Husband of Sara, journeyman cloth shearer

Father of Sara, master cloth shearer

\section{Clergy}

Pastor (parish priest) of the Catholic parish of Vaals

Curate (assistant priest) of the Catholic parish of Vaals

Curate of the (Catholic) parish of St. Adalbert, Aachen 
Petrus Rademacker

Johannes Pferdmenges

Anna Olivier

Martinus Buntgens

Andries Buntgens

Conrad Wolff

Sebastian Gimmenich

Johannes Grommet

Hendrick Lotmans

Pieter Koetgens

Abraham van den

Heuvel

Willem Frederik de Jacobi de Cadier

Count Charles Bentinck, Lord of Nijenhuis

Johan Frans à Brassard

Isaac Daniel Fellinger

Peter Strauch
Father Bosten's predecessor

Calvinist minister for Burtscheid

\section{Villagers}

Midwife

Sexton of the Catholic parish of Vaals

Father of Martinus, courier

Blacksmith

Rioters

Farmhand at Melaten, later farmer of the Grosse Neuenhof

Farmhand

Servant of Conrad Wolff

Farmhand (innocent)

\section{Officials}

Lieutenant governor (lieutenant drossaard) of the Land of 's-

Hertogenrade; dies August i 762

Successor of Van den Heuvel as lieutenant governor

Governor (hoog drossaard) of the

Land of 's-Hertogenrade

Burgomaster of Vaals

Secretary of the Vaals district court; dies June I 764

Burgomaster of Aachen 
Lawyers

Stephan Arnold

Schmalhausen

H. J. Wilkin

Johann Wilhelm

Hasenclever

J. J. Levericksvelt

Johann Arnold von

Clermont
Solicitor for Father Bosten; deacon of the Vaals Reformed congregation

Barrister for Father Bosten

Solicitor for the lieutenant governor; succeeds Fellinger as court secretary Barrister for the lieutenant governor

Other

Textile manufacturer 


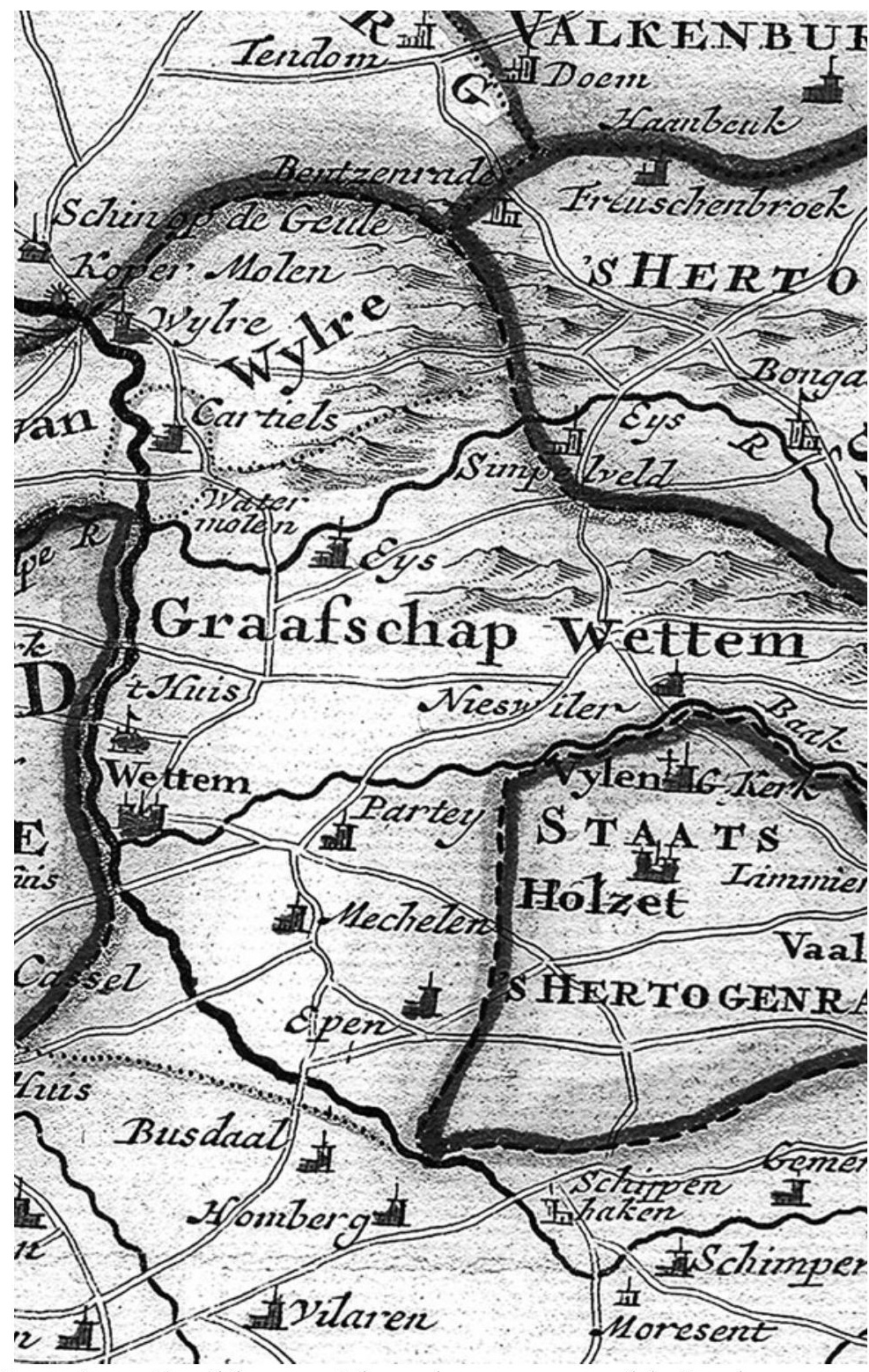

I. Vaals and its environs. Detail from an eighteenth-century map of the Lands of Overmaas. 


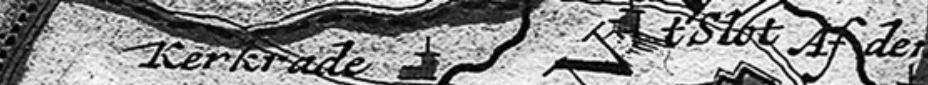

OOSTENRYIS Wv trit

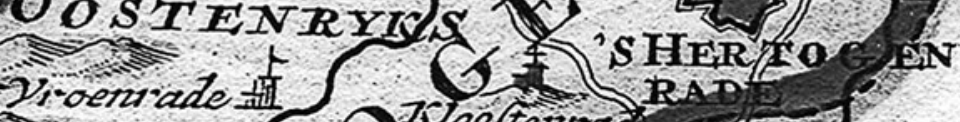

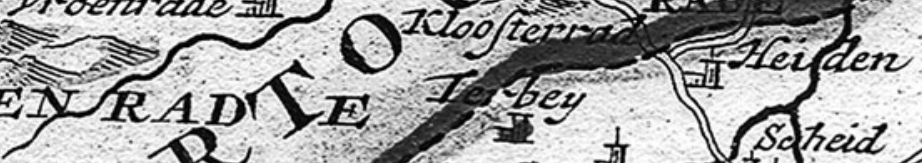

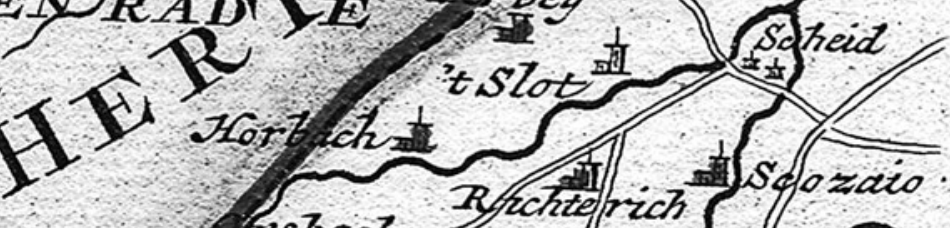

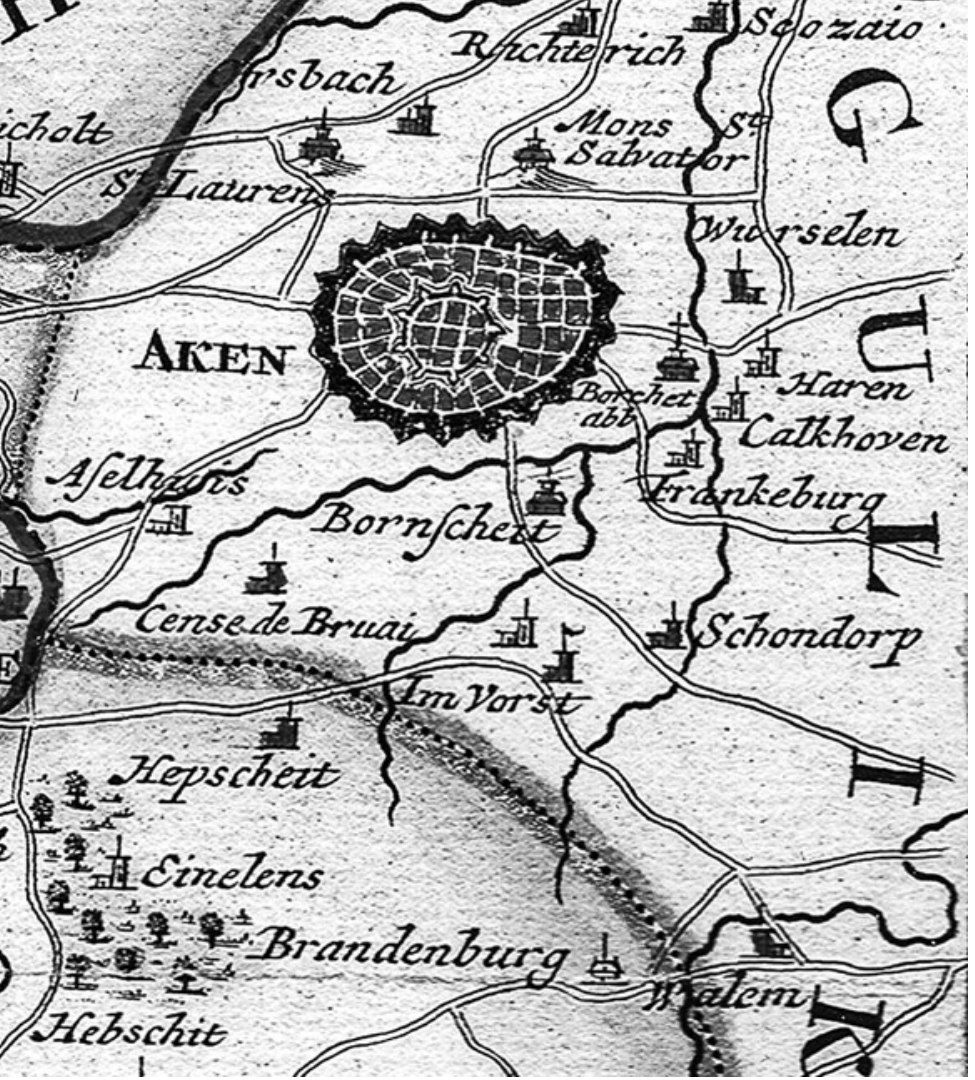


This page intentionally left blank 
Cunegonde's Kidnapping 
This page intentionally left blank 